\title{
PERANCANGAN SISTEM ADMINISTRASI PADA GUGUNS BENGKEL MOTOR JAKARTA BERBASIS JAVA
}

\author{
Danan Wiwoho', Imam Himawan ${ }^{2}$, Intan Mutia ${ }^{3}$ \\ 1,2,3 Universitas Indraprasta PGRI \\ Jl. Raya Tengah No.80, Kel Gedong, Kec. Pasar Rebo, Jakarta Timur \\ 1.dananwiwoho21@gmail.com, $\underline{\text { imamhimawann@gmail.com, }}$ ㄹas.syifaraa@gmail.com
}

\begin{abstract}
ABSTRAK
Kebutuhan akan keberadaan bengkel motor dari tahun ke tahun mengalami peningkatan yang signifikan. Data dari Asosiasi Industri Sepeda Motor (AISI) menunjukkan rasio perbandingan antara penjualan sepeda motor dengan penambahan kapasitas bengkel adalah 5:1 yang berarti setiap penjualan lima sepeda motor hanya diikuti oleh penambahan satu kapasitas bengkel motor. Hal tersebut di lihat sebagai peluang bisnis yang baik oleh pemilik Guguns Bengkel Motor Jakarta. Namun dalam menjalankan bisnisnya selama ini masih menggunakan pencatatan secara manual yang terkadang membuat kerugian baik dalam hal materi maupun kepercayaan pelanggan. Tujuan penelitian ini untuk mengatasi permasalahan yang ada, dengan merancang sistem pengolahan data servis motor dan penjualan suku cadang secara terintegrasi dan terorganisir lebih baik dengan mamanfaatkan teknologi informasi yang sudah berkembang pesat. Metode pengembangan sistem yang digunakan menggunakan metode research and development $(R \& D) /$ forward engineering research. Dimana dalam membuat sistem ini perlu alat bantu perancangan sistem yaitu Diagram Alir Data (DAD) Konteks, Nol dan Rinci serta dengan menggunakan bahasa pemrograman Java dengan Netbeans dan database MySQL menggunakan XAMPP. Perancangan sistem informasi administrasi pada Guguns Bengkel Motor Jakarta menggunakan java, bisa memudahkan pekerjaan bagian administrasi. Dalam mendata pelanggan, servis motor, penjualan suku cadang, dan laporan lebih mudah melakukan pendataan dan penyimpanan data dengan tingkat efektivitas dan konsisten data lebih terjamin.
\end{abstract}

Kata Kunci: Aplikasi, Bengkel Motor, Java, Administrasi, Netbeans

\begin{abstract}
The need for the existence of a motorcycle workshop from year to year has increased significantly. Data from the Motorcycle Industry Association (AISI) shows that the ratio between motorcycle sales and the addition of workshop capacity is 5:1, which means that every sale of five motorcycles is followed by the addition of one motorcycle repair shop capacity. This is seen as a good business opportunity by the owner of Guguns Bengkel Motor Jakarta. However, in running their business so far they still use manual recording which sometimes makes losses both in terms of material and customer trust. The purpose of this research is to overcome the existing problems, by designing a data processing system for motorcycle services and sales of spare parts in an integrated and better organized manner by utilizing information technology that has developed rapidly. The system development method used is research and development $(R \& D) /$ forward engineering research. Where in making this system we need system design tools, namely Context, Zero and Detailed Data Flow Diagrams (DAD) and using the Java programming language with Netbeans and MySQL database using XAMPP. The design of the administrative information system at Guguns Bengkel Motor Jakarta using Java, can facilitate the work of the administration section. In registering customers, servicing motorcycles, selling spare parts, and reporting, it is easier to collect and store data with a more guaranteed level of effectiveness and consistent data.
\end{abstract}

Key Word: Applications,motorcycle workshop, Java, Administration, Netbeans

\section{PENDAHULUAN}

Salah satu layanan jasa yang mengandalkan kualitas pelayanan untuk menarik dan mempertahankan pelanggannya adalah Guguns Bengkel Motor di kota Jakarta. Bengkel motor ini memiliki dan menyediakan berbagai fasilitas yang bertujuan untuk memperbaiki sepeda motor yang mengalami gangguan atau kerusakan. Namun, dalam melakukan proses usahanya masih menggunakan cara manual yang terkadang menyebabkan kerugian baik dalam hal penghasilan maupun human eror. Berdasarkan hasil analisa yang telah di jalankan beberapa permasalahan yang ada pada sistem yang sedang berjalan, antara lain tingginya tingkat kesalahan manusia (human error) sehingga 
sering terjadinya kesalahan pada saat pencatatan pesanan dan pembuatan laporan.

Analisis permasalahan yang dapat di simpulkan dari hasil penelitian yang dilakukan di Guguns Bengkel Motor, yaitu analisis data dan analisis proses. Tujuan penelitian yaitu, merancang sistem pengelolaan data servis motor dan penjualan suku cadang secara terintegrasi dan terorganisir lebih baik dengan memanfaatkan teknologi yang sudah berkembang pesat.

Metodologi untuk penelitian ini menggunakan metode pendekatan kualitatif, dengan mengumpulkan data yang berhubungan dengan masalah - masalah yang diteliti. Masalah lain yang ada di Guguns bengkel motor yaitu belum adanya pembuatan laporan penjualan dan pelayanan, mereka hanya menggunakan rekap nota untuk laporan. Utntuk pemecahan masalah tersebut yaitu membuat perancangan sistem informasi administrasi yang dapat membantu pekerjaan di bengkel dan menggabungkan komponen-komponen yang masih belum terkomputerisasi ke dalam satu sistem dan menjamin fungsi-fungsi sistem itu dapat digunakan untuk meningkatkan pelayanan penjualan barang dan jasa Guguns bengkel motor. Dengan adanya Sistem Informasi itu memudahkan dalam pengelolaan pengerjaan data administrasi pada Guguns bengkel motor. Pengolahan data menjadi lebih cepat, keamanan dan akurasi data lebih terjamin.

"Pada dasarnya metode penelitian merupakan tata cara, langkah, atau prosedur yang ilmiah dalam mendapatkan data untuk tujuan penelitian yang memiliki tujuan dan kegunaan tertentu. Secara umum tujuan penelitian ada tiga macam, yaitu yang bersifat penemuan, pembuktian, dan pengembangan." Sugiyono (2018:2)

\section{METODE PENELITIAN}

Dalam melakukan penelitian perlu suatu metode penelitian yang sesuai dengan pokok permasalahan yang akan di teliti. Untuk penelitian tersebut menggunakan bentuk penelitian pengembangan (research and development $(R \& D) /$ forward engineering research) yang menggunakan pendekatan terstruktur. Forward engineering research yang dilakukan dari identifikasi masalah, pengumpulan informasi, penyusunan bentuk model, pengujian bentuk model, pem- bangunan, membuat evaluasi, dan menentukan validasi. Penelitian dilakukan dari tingkat yang lebih tinggi menuju ke tingkat yang lebih rendah, sehingga dapat menguji bentuk teori, model, dan formula (confirmatory research).

Dalam perancangan sistem pengelolaan bengkel motor, rancangan kegiatan yang dilakukan penulis yaitu : 1) Mengidentifikasi suatu masalah, suatu tujuan, dan syarat informasi; 2) Menganalisa ke-butuhan suatu sistem; 3) Studi tentang ke-pustakaan; 4) Perancangan suatu sistem; 5) Implementasi dan pengujian suatu sistem; 6) Penulisan suatu laporan.

Penelitian ini dilakukan pada salah satu penyedia jasa bengkel motor yang bernama Guguns Bengkel Motor di Jl. H. Karim No. 30 RW 05, Setu, Cipayung Jakarta Timur 13880 , nomer telp 089517045869.

Metode yang dilakukan penulis untuk mengumpulkan data yaitu : 1) Metode Kepustakaan yaitu pengumpulan data dan informasi dari kutipan-kutipan berbagai buku, peraturan perundang-undangan, serta hasil laporan dan bahan yang lain berkaitan dengan penelitian. 2) Metode Observasi merupakan cara pengumpulan data dengan pengamatan lansung dan pencatatan data secara sistematis untuk obyek yang akan diteliti. 3) Metode Wawancara merupakan suatu teknik untuk mengumpulkan informasi dengan cara bertanya dan menjawab antara penanya dengan responden. Wawancara dilakukan dengan Bapak Gugun Gunawan selaku pemilik Guguns Bengkel Motor Jakarta.

\section{HASIL DAN PEMBAHASAN}

Penyelesaian masalah yang ada pada Guguns bengkel motor adalah membuat sebuah aplikasi perancangan sistem informasi administrasi pada Gugun Bengkel Motor dengan menggunakan bahasa pemrograman java dan penyimpanan data-data pada media database. Dengan usulan ini diharapkan permasalahan pada pengolahan data-data administrasi pada gugun bengkel motor dapat tertangani dengan cepat dan akurat. Adapun dekomposisi sistem yang sudah diusulkan pada Guguns Bengkel Motor Jakarta adalah: 


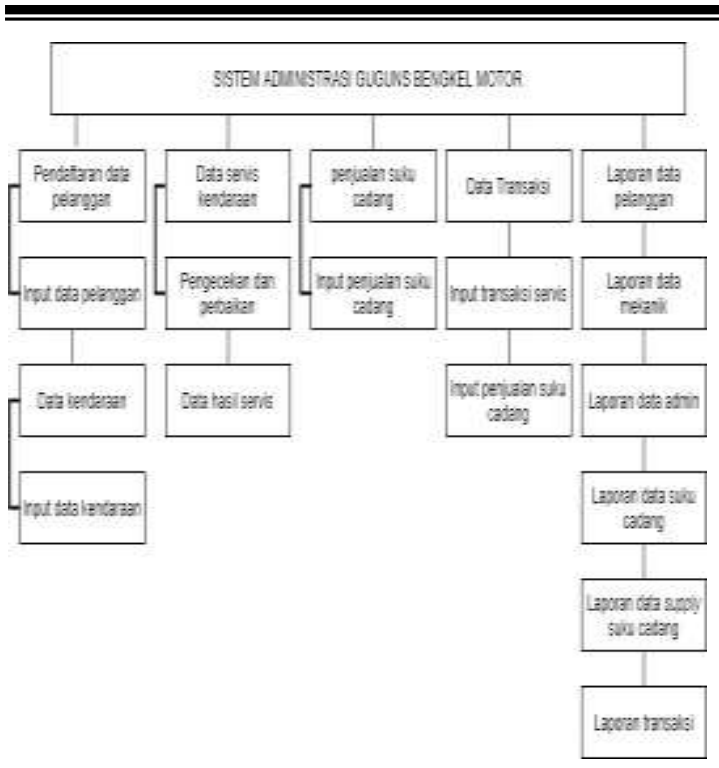

Gambar 1. Dekomposisi Fungsi Sistem Diusulkan

Diagram konteks yang diusulkan pada Guguns bengkel motor Jakarta dapat digambarkan sebagai berikut :

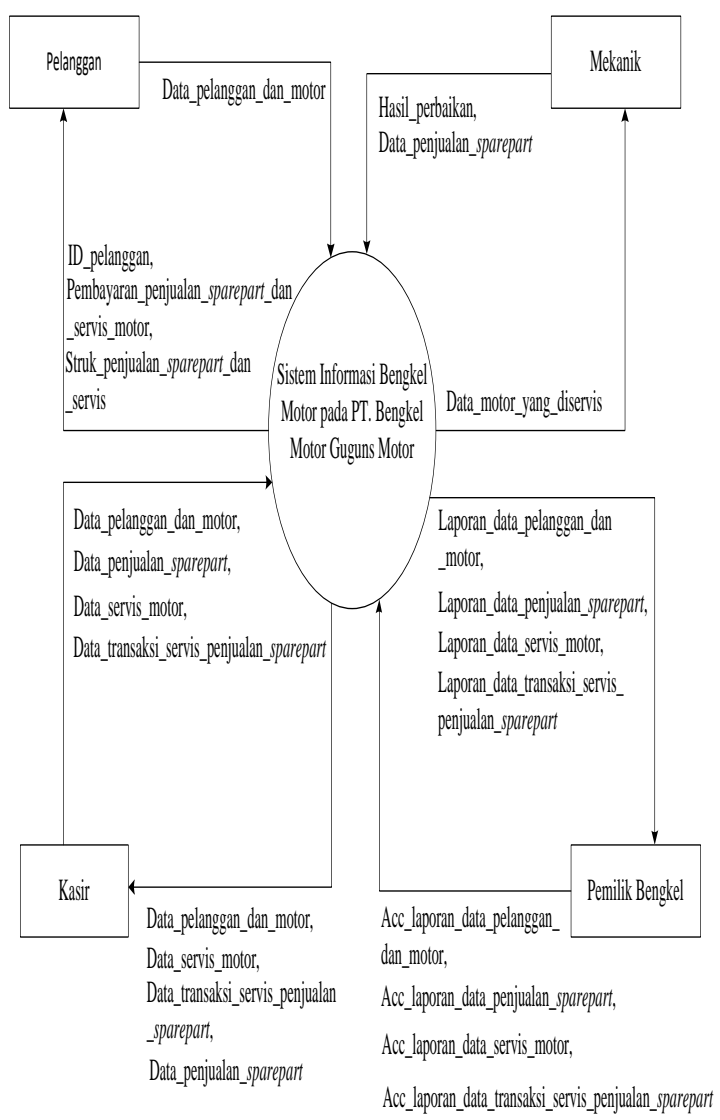

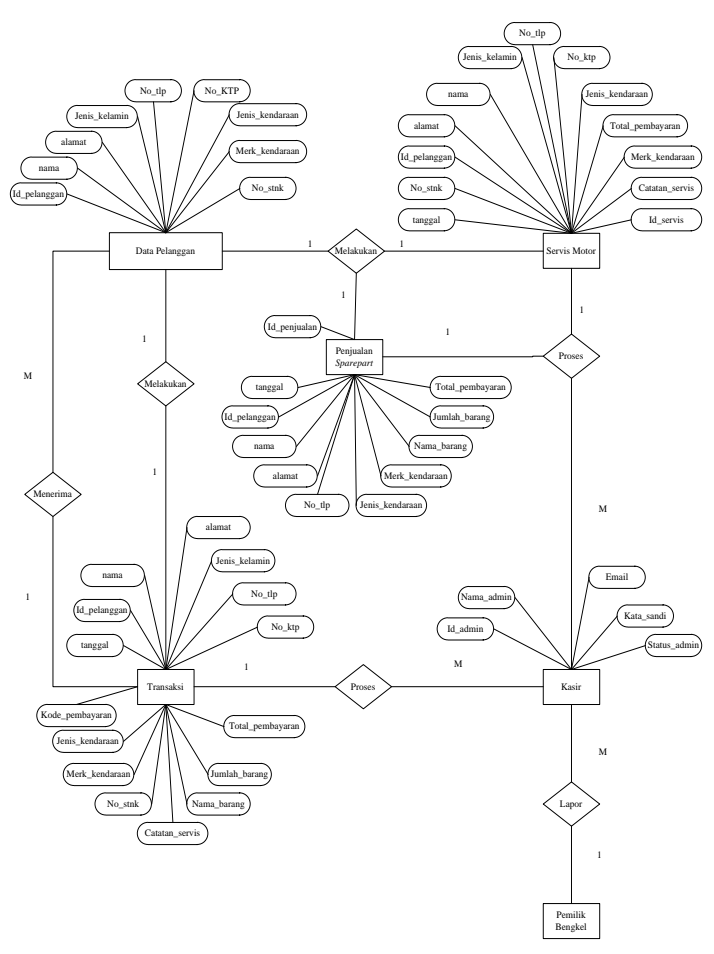

Gambar 3. Entity Relationship Diagram (ERD)

Berikut ini adalah tampilan dari perancangan sistem administrasi Guguns bengkel motor Jakarta yang dibuat dengan bahasa pemrograman Java dan IDE Netbeans dan database menggunakan MySQL :

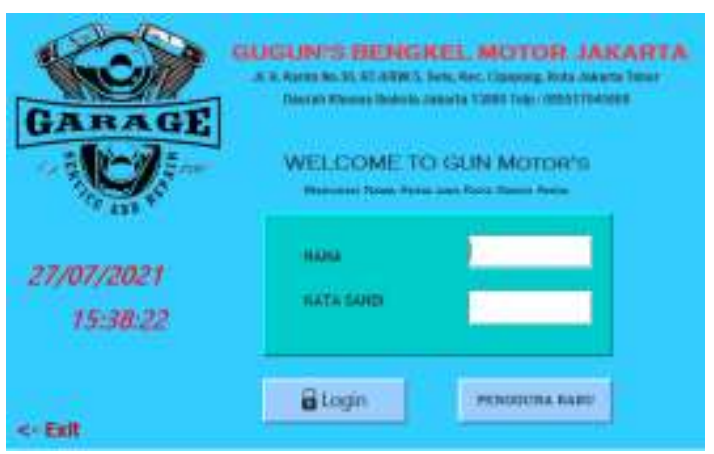

Gambar 4. Tampilan Login

Tampilan menu form login muncul saat program pengoperasian sistem administrasi diisi oleh bagian admin. Jika nama user dan kata sandi tidak salah akan masuk ke dalam tampilan menu utama.

Gambar 2. Diagram Konteks Sistem Diusulkan 


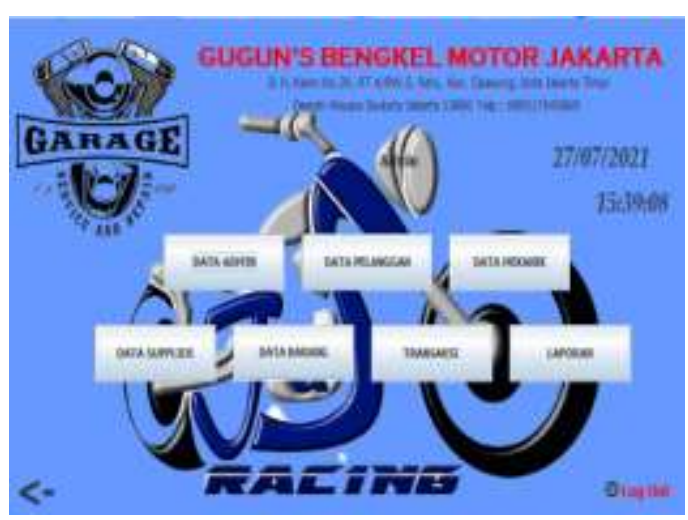

Gambar 5. Tampilan Menu Utama

Tampilan menu utama terdapat jenis menu yang di tampilkan form-form data admin, data pelanggan, data mekanik, data supplier, data barang, transaksi, dan laporan.

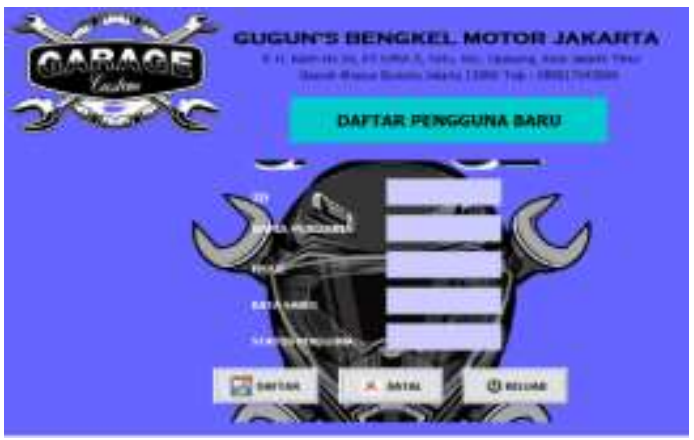

Gambar 6. Tampilan Data Pelanggan

Tampilan diatas merupakan tampilan form untuk menginput data pelanggan baru yang di miliki Bengkel Guguns ke dalam suatu database dan untuk pencarian data pelanggan dapat di klik tombol daftar yang akan menampilkan data-data pelanggan yang sudah terdaftar pada Guguns bengkel motor Jakarta.

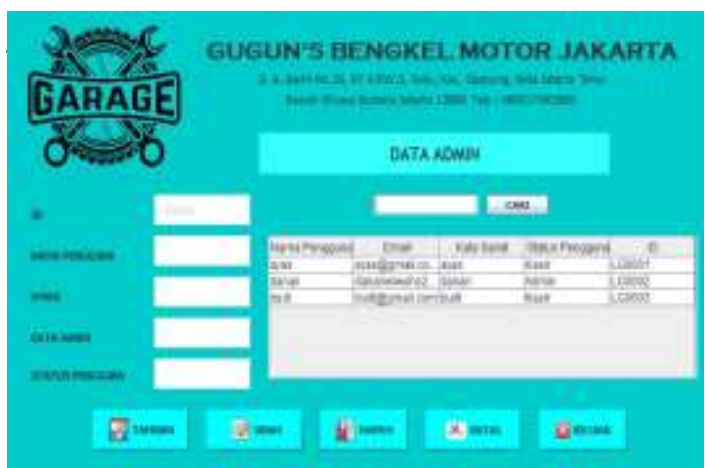

Gambar 7. Tampilan Data Admin

Tampilan form data admin pada gambar di atas digunakan untuk menginput admin yang bertugas dan sudah teregistrasi pada sistem aplikasi Guguns Bengkel.

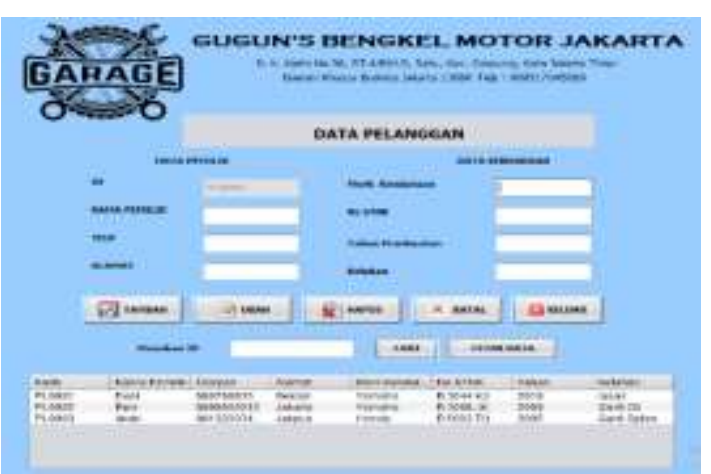

Gambar 8. Tampilan Data Pelanggan

Tampilan diatas merupakan rancangan tampilan form dari data pelanggan yang digunakan untuk memasukkan data-data pelanggan Guguns Bengkel Motor. Memudahkan data pelanggan supaya tidak terjadi kerangkapan data maka setelah melakukan proses pendaftaran pelanggan akan menerima sebuah kartu sebagai identitas guna memudahkan untuk pencarian data dan penyimpanan data.

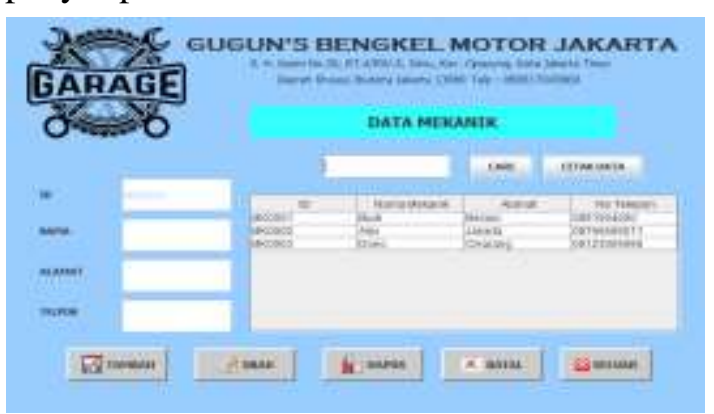

Gambar 9. Tampilan Data Mekanik

Tampilan diatas merupakan rancangan tampilan form data mekanik digunakan untuk memasukkan data para pekerja mekanik Guguns Bengkel Motor.

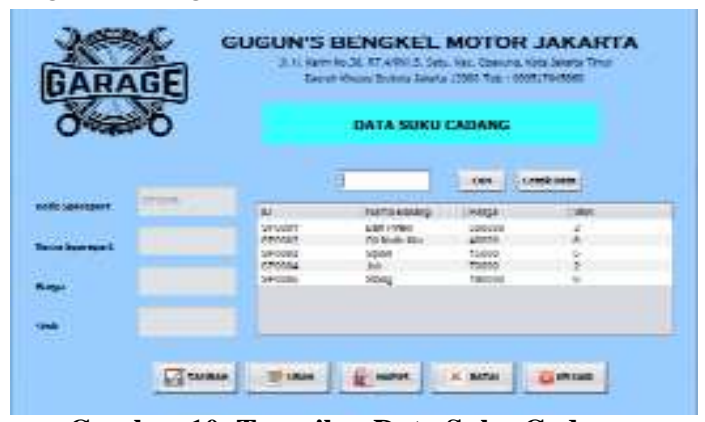

Gambar 10. Tampilan Data Suku Cadang

Tampilan form suku cadang digunakan untuk data suku cadang atau barang yang tersedia pada database di Guguns Bengkel Motor. 


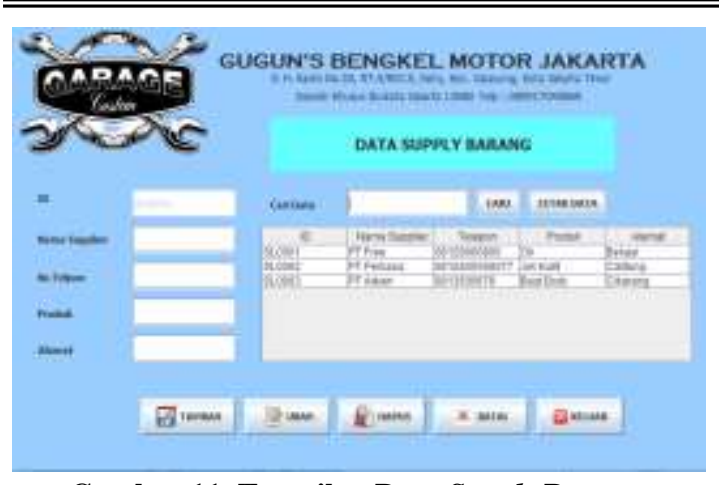

Gambar 11. Tampilan Data Supply Barang

Tampilan diatas merupakan rancangan tampilan form data supply barang yang di gunakan untuk pemesanan barang pada supplier di menu database Guguns Bengkel Motor jika barang di etalase bengkel sudah habis atau tidak tersedia.

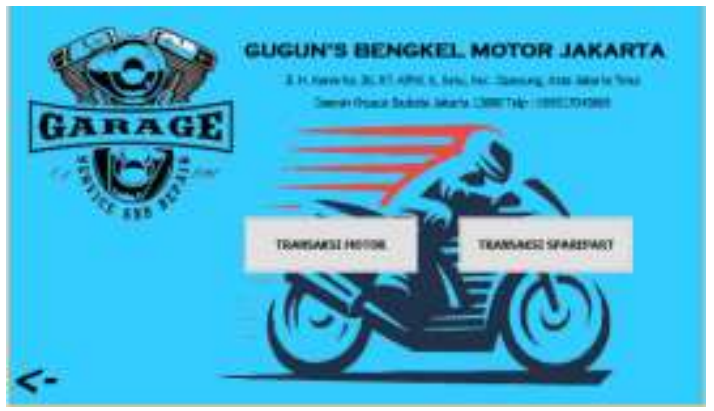

Gambar 12. Tampilan Data Transaksi

Tampilan diatas merupakan rancangan menu awal tampilan form data transaksi motor dan transaksi sparepart yang akan menampilkan menu data-data transaksi motor dan data-data transaksi sparepart yang lengkap. Setelah di klik menu ini akan menampilkan menu transaksi motor dan transaksi sparepart yang lengkap dengan data pelanggan ataupun catatan perbaikan motor oleh mekanik.

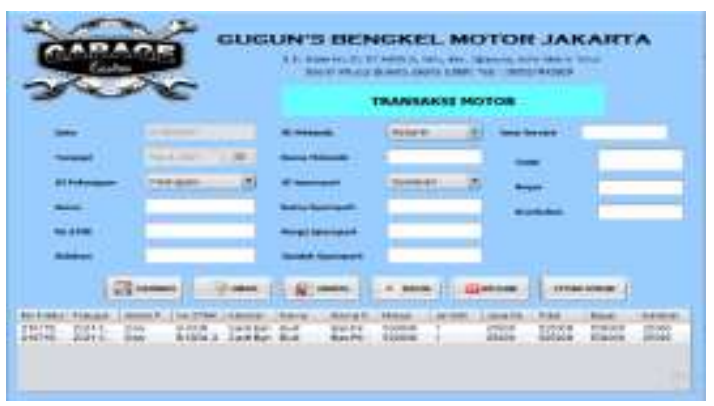

Gambar 12. Tampilan Data Transaksi Motor

Tampilan form diatas digunakan untuk menginput dan menampilkan data transaksi motor serta dapat menampilkan harga untuk jumlah yang akan di bayarkan oleh pelanggan jika kendaraan telah selesai di perbaiki oleh mekanik.

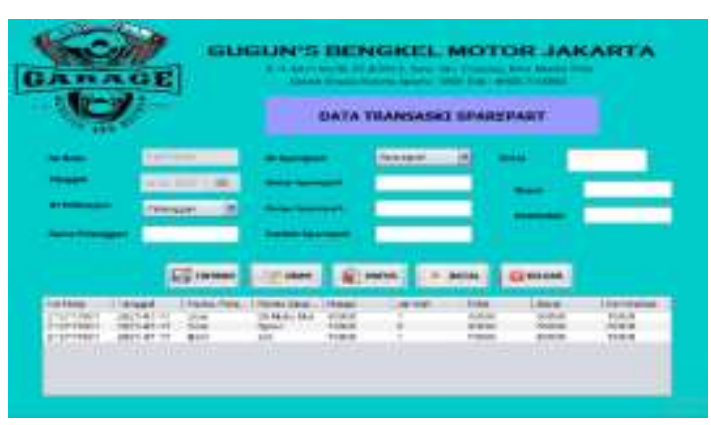

Gambar 13. Tampilan Data Transaksi Sparepart

Tampilan form diatas digunakan untuk menginput dan menampilkan data transaksi Sparepart serta dapat menampilkan harga untuk jumlah yang akan di bayarkan oleh pelanggan. Form ini hanya untuk pembelian barang saja tanpa perbaikan atau pemasangan oleh mekanik.

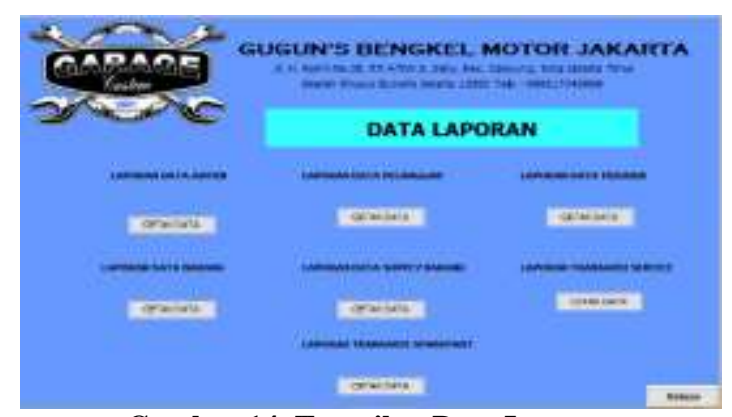

Gambar 14. Tampilan Data Laporan

Tampilan form diatas digunakan untuk mencetak laporan data pelanggan, data mekanik, data barang, data supply barang, data transaksi servis motor dan data transaksi sparepart kemudian di berikan ke pemilik bengkel.

\section{SIMPULAN DAN SARAN}

Penyajian informasi yang cepat, tepat dan akurat sangat penting bagi pertumbuhan dan perkembangan suatu organisasi atau instansiinstansi. Sejalan dengan perkembangan ilmu pengetahuan dan teknologi yaitu dengan adanya sistem pengolahan data dengan aplikasi yang nantinya bisa menggantikan sistem terdahulu yang menggunakan Ms. Office.

Dari hasil penelitian perancangan, implementasi, dan proses uji coba perangkat lunak dapat disimpulkan sebaga berikut: 1) Perancangan sistem informasi administrasi pada Guguns Bengkel Motor Jakarta berbasis java, dapat meringankan pekerjaan bagian administrasi. Data pelanggaan, data motor, data penjualan suku cadang serta laporan 
transaksi, dapat mudah melakukan pendataan dan penyimpanan dengan tingkat efektivitas dan konsisten data yang lebih terjamin. 2) Aplikasi ini dirancang agar mudah dioperasikan, ukuran berkas file executable yang kecil serta rancangan tampilan yang sederhana sehingga admin mudah dalam mengoperasikan dan bisa bekerja dengan lebih baik, lebih cepat dalam memasukkan, mengolah, dan menyimpan data laporan.

Adapun saran pada Perancangan Sistem Informasi Administrasi pada Guguns Bengkel Motor Jakarta ini diharapkan mampu memberikan manfaat bagi pemilik bengkel. Untuk mendapatkan manfaat yang maksimal, maka penulis mengajukan beberapa saran untuk pengetahuan pada Sistem Informasi Administrasi Guguns Bengkel Motor Jakarta: 1)Perancangan Sistem Informasi Administrasi Guguns Bengkel Motor Jakarta dapat dikembangkan kembali dalam hal desain atau penambahan database sesuai kebutuhan pengolahan data Sistem Informasi Administrasi Guguns Bengkel Motor Jakarta. 2) Sistem Informasi Administrasi Guguns Bengkel Motor Jakarta memerlukan hasil laporan yang lebih tersusun. 3) Sistem ini di harapkan dapat berkembang dan di manfaatkan tanpa adanya penyalahgunaan pada informasi.

Penulis menyadari masih banyak kekurangan dalam pembuatan Sistem Informasi Administrasi Guguns Bengkel Motor Jakarta ini. Maka dari itu penulis berharap sistem ini dapat dikembangkan lebih baik lagi dan mendapatkan saran yang lebih baik lagi untuk penulis.

\section{UCAPAN TERIMAKASIH}

Ucapan terima kasih dari penulis sampaikan terutama untuk dosen pembimbing materi, dosen Pembimbing Teknik, Ibu Mei Lestari, M.Kom selaku Ketua Program Studi Informatika, Bapak Gugun Gunawan selaku pemilik Gugun Bengkel Motor Jakarta yang telah memberi kesempatan untuk menganalisa dan menjadikan objek tempat penelitian saya sehingga tugas akhir saya bisa diselesaikan pada perusahaannya. Terima kasih pula kepada kedua orang tua saya yang selalu memberikan semangat dan doa yang tiada henti untuk saya, terima kasih kepada Sintia Widiastuti selaku support system saya dalam mengerjakan tugas akhir ini hingga selesai, serta teman-teman kelas SA angkatan 2017 dan terima kasih kepada semua untuk waktu dan tempat yang telah ikut terlibat penelitian di dalam tugas akhir saya.

\section{DAFTAR PUSTAKA}

Aris e., (2017)Aris, A., Rinja, M., \& Jherico, T. (2017). Aplikasi Sistem Penjualan Sparepart Motor Pada Bengkel Barokah Motor Berbasis Web. Technomedia Journal. https://doi.org/10.33050/tmj.v2i1.318

Erwan, L. V, Yulia, Y., \& Rostianingsih, S. (2018). Sistem Informasi Administrasi Servis dan Penjualan Motor Honda pada CV Anugrah Jaya Sumenep. Jurnal Infra.

Gunawan, I. (2014). Metode Penelitian Kualitatif: Teori dan Praktik. In Jakarta: Bumi Aksara.

Hariyanto, B. (2011). Esensi-esensi Bahasa Pemrograman Java. Informatika. Bandung.

Madcom. (2016). Pemrograman PHP dan MySQL Untuk Pemula. In Yogyakarta: C.V Andi.

Nugroho, S. E., \& Siang, J. J. (2015). Sistem Informasi Pelayanan Jasa Service Sepeda Motor Studi kasus : Naga Mulya Motor Yogyakarta. Jurnal EKSIS.

Pratama, B. G., Raharjo, Y., \& Ardhi M, M. (2015). Rancang Bangun Sistem Informasi Manajemen Bengkel Bubut Berbasis Desktop pada Bengkel Berkah. Jurnal Rekayasa Dan Teknologi Elektro Universitas Lampung, 9(2).

Saputro, E. B., \& Rachmatullah, R. (2020). Sistem Informasi Manajemen Bengkel Bowo Motor Sragen. Go Infotech: Jurnal Ilmiah ....

Simatupang, J. (2019). Perancangan sistem informasi jasa servis kendaraan dan penjualan suku cadang pada Jaya Bersama. Jurnal Intra-Tech.

Welim, Y. Y., T.W., W., \& Firmansyah, R. (2015). Pengembangan Sistem Informasi Service Kendaraan Pada Bengkel KFMP. Simetris: Jurnal Teknik Mesin, Elektro Dan Ilmu Komputer. https://doi.org/10.24176/simet.v6i1.232 